\title{
Identify a Good New Potential Zones for Hydrocarbon Reservoir Formation, Using Seismic Data Interpretation, Attributes and 3d Modeling in Komombo Basin, Southern Western Desert, Upper Egypt
}

\author{
Adel A. A. Othman ${ }^{1}$, Tharwat H. Abdel Hafez ${ }^{1}$ and M. Ibrahim El-Aswany ${ }^{2}$ \\ ${ }^{1}$ (Geology Department Faculty of Science, Al-Azhar University, Nasr City, Cairo Egypt) \\ ${ }_{2}^{2}$ (Qarun Petroleum Company, Maadi, Cairo, Egypt)
}

\begin{abstract}
The abstract should summarize the content of the paper. Try to keep the abstract below 200 words. Do not make references nor display equations in the abstract. The journal will be printed from the same-sized copy prepared by you. Your manuscript should be printed on A4 paper $(21.0 \mathrm{~cm} \times 29.7 \mathrm{~cm})$. It is imperative that the margins and style described below be adhered to carefully. This will enable us to keep uniformity in the final printed copies of the Journal. Please keep in mind that the manuscript you prepare will be photographed and printed as it is received. Readability of copy is of paramount importance.
\end{abstract}

Keywords: Six hills, Abu Ballas, Komombo Basin, Reservoir Characterization, Upper Egypt.

\section{Introduction}

Komombo Concession in which the study area is located on the west bank of the Nile River, about 570 $\mathrm{km} \mathrm{SSE}$ of Cairo, and about $260 \mathrm{~km}$ east of the Red Sea. (Fig.1) As the Geographic system, it lies between: Latitudes $24^{\circ} 10^{\prime} 00^{\prime \prime} \mathrm{N} \& 24^{\circ} 42^{\prime} 00^{\prime \prime} \mathrm{N}$ and Longitudes $32^{\circ} 55^{\circ} 00^{\prime \prime} \mathrm{E} \& 32^{\circ} 40^{\circ} 00^{\prime \prime} \mathrm{E}$ and as the Metric system, it lies between $\mathbf{X}$ is $809635.57 \mathrm{~m} \mathrm{E} \& 783510.95 \mathrm{~m} \mathrm{E}$ and $\mathbf{Y}$ is $164949.86 \mathrm{~m} \& 223715.46 \mathrm{Mn}$

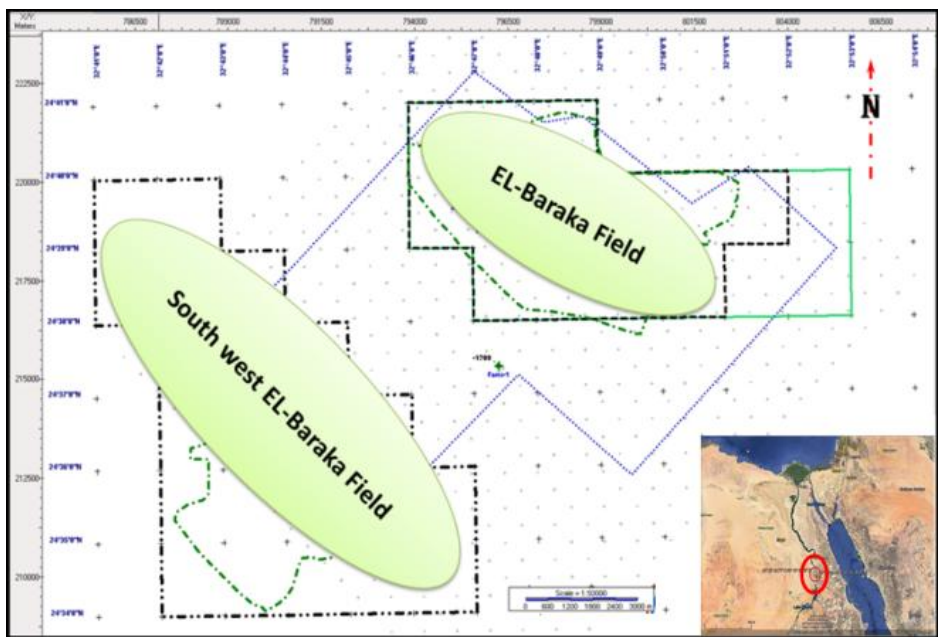

Fig. 1 Location map of Komombo

\section{Geological Setting}

The studied area is lies in the Southern part of Western Desert in Upper Egypt to the North of Aswan city.

2.1 Stratigraphicsetting:

The Western Desert is a huge platform with mean elevation of 500 meter above sea level consisting of thick-layered sedimentary rocks largely unaffected by tectonic disturbances (9). The Western Desert of Egypt consists of a series of small rift basins. Although some are of Permian age, (3) considered that most were initiated in the Late Jurassic-Early Cretaceous. There are four regional tectonic elements that have contributed to shaping structures in southern Egypt. The first of these tectonic elements is the NW-trending Precambrian Najd faultsystem.Mesozoic rifting that affected northern and central Africa might be the second tectonic element that shaped the structure dominating southern Egypt today. Around the Aswan area, (9) showed in their regional synthesis of northern Africa that a NW-trending rift was developed during the Campanian- Maastrichtian time (_74 Ma). Subsequently, (2) suggested that there are at least two NW-trending grabens (Asyut and Kom Ombo) formed in southern Egypt along the modern Nile Valley during the Jurassic - Early Cretaceous.This basin is a 
complex and composite structure including marginal or sag The Mesozoic units include the Jurassic-Lower Cretaceous Abu Ballas Formation, Lower Middle Cretaceous El-Burg Formation, the Cenomanian Bahariya, Formation, the Middle-Upper Cenomanian Heiz Formation, the Coniacian-Maastrichtian Taref Sandstone (lower Member of the Nubia Formation), the Santonian-Campanian Quseir Clastic (upper Member of the Nubia Formation), the Duwi Formation, (Campanian-Lower Maastrichtian), the Dakhla Formation, and the Khoman Chalk (Upper Maastrichtian). Fig (2).

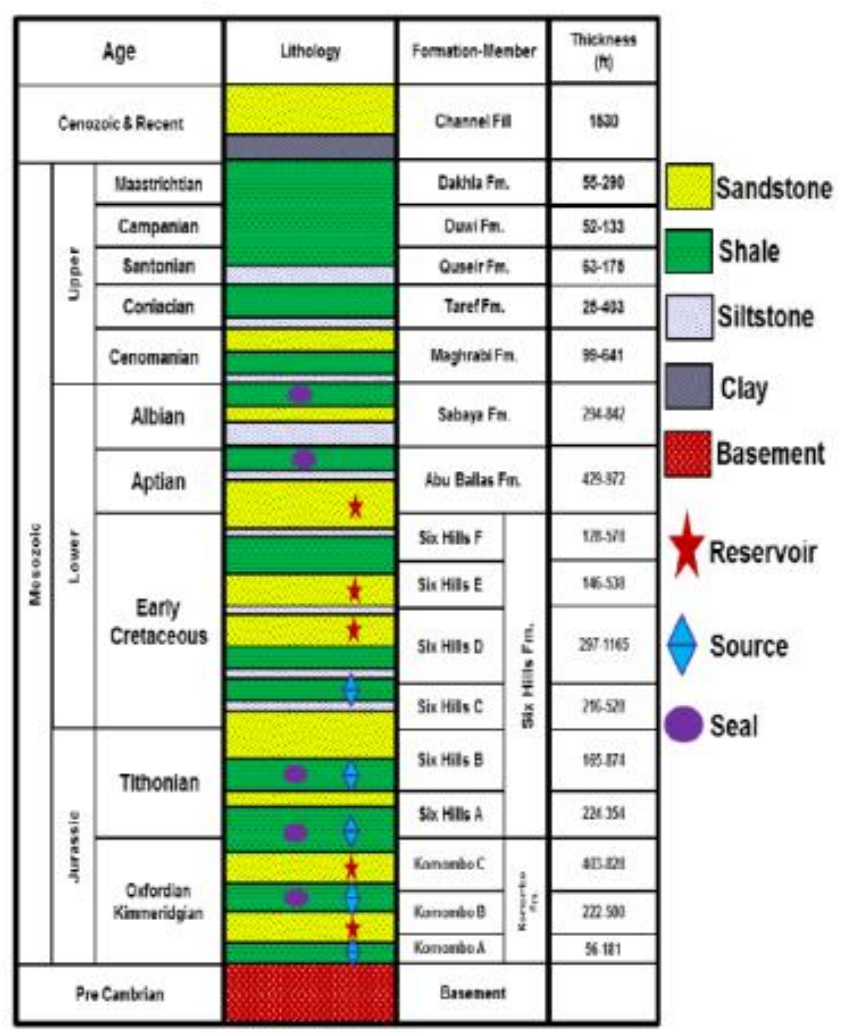

Fig. 2 Stratigraphic Column and Petroleum elements of Komombo Basin Area (7).

\subsection{Structural Setting}

The Western Desert of Egypt consists of a series of small rift basins. Although some are of Permian age, (3) considered that most were initiated in the Late Jurassic-Early Cretaceous, contemporaneous with the creation of the Mediterranean basins and with the southernmost Sirte rifts in Libya. This basin is a complex and composite structure including marginal or sag. The Kom Ombo sub-basin is a grabenal area within the Precambrian basement rocks of the Red Sea Hills in the south part of the Eastern Desert. (fig 3).

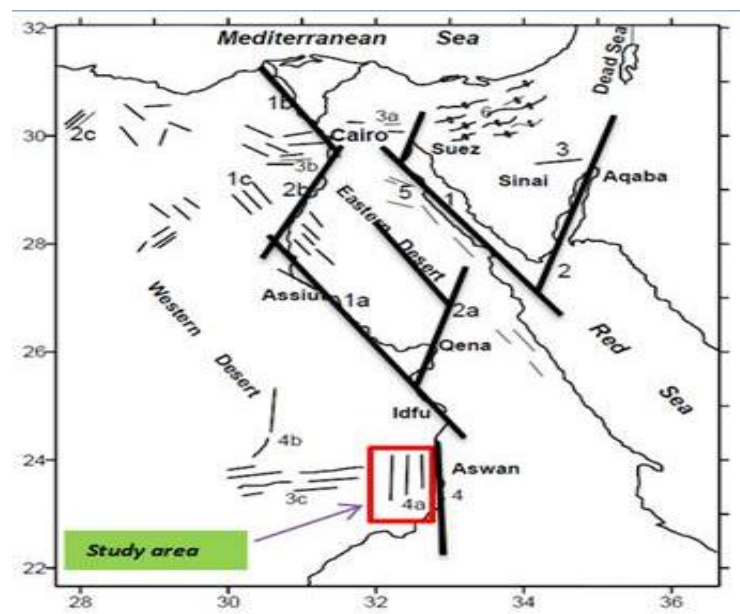

Fig. 31 a , 1b, 1c = Gulf of Suez trend (about N35o W); 2, 2a, 2b, 2c = Gulf of Aqaba trend (about N15o E); 3 (Central Sinai fault), 3a, 3b, 3c = east west trend; 4, 4a, 4b = north south trend; $5=$ N45o W. (After 10). 
Egypt has seven main tectonic trends, which vary in strength and prevalence throughout the country (Fig.2) north-south (Nubian trend); north-northeast (Aqaba trend); east-west (Tethyan trend); west-northwest (Darag trend); east-northeast (Syrian Arc trend); northeast (Tibesti trend), and northwest (Red Sea trend) (5). The east-west Tethyan trend, i.e. the Kalabsha fault, and the northwest Red Sea trend are the dominant fault trends in the Aswan area.basin, where it is closed by a northern basement arch (4).This basin is a complex and composite structure including marginal or sag The Mesozoic units include the Jurassic-Lower Cretaceous Abu Ballas Formation, Lower Middle Cretaceous El-Burg Formation, the Cenomanian Bahariya, Formation, the Middle-Upper Cenomanian Heiz Formation, the Coniacian-Maastrichtian Taref Sandstone (lower Member of the Nubia Formation), the Santonian-Campanian Quseir Clastic (upper Member of the Nubia Formation), the Duwi Formation, (Campanian-Lower Maastrichtian), the Dakhla Formation, and the Khoman Chalk (Upper Maastrichtian).(fig 4).

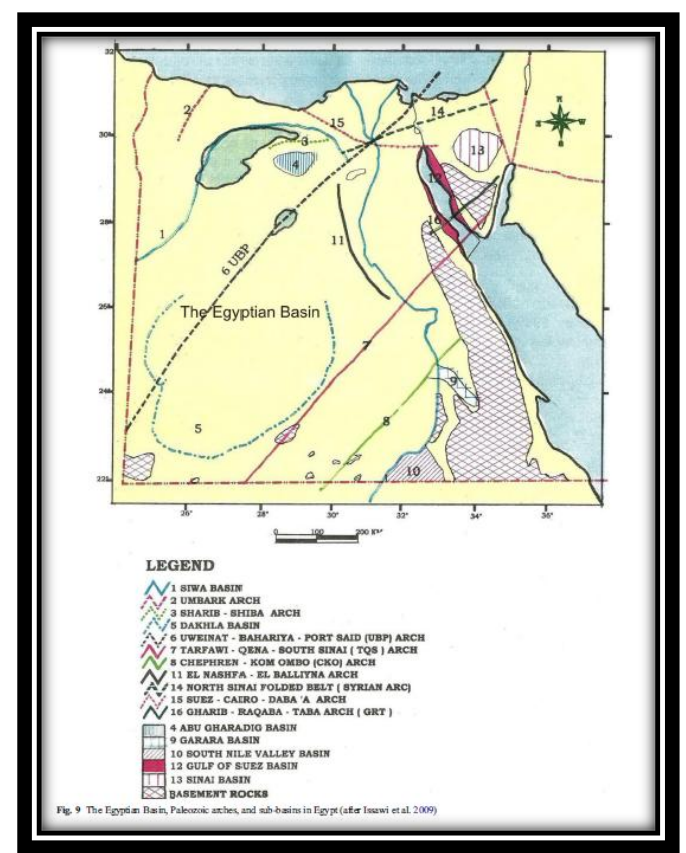

Fig. 4 The Egyptian Basin, Paleozoic arches, and sub-basins in Egypt (after 4 )

Lineament bounds the northern side of the Kom Ombo sub- basin in the north and south Nile Valley sub-basin in the south. These are separated by a dissected basement wall. The two sub-basins have different lithostratigraphic successions.

\section{SEISMIC DATA INTERPRETAION}

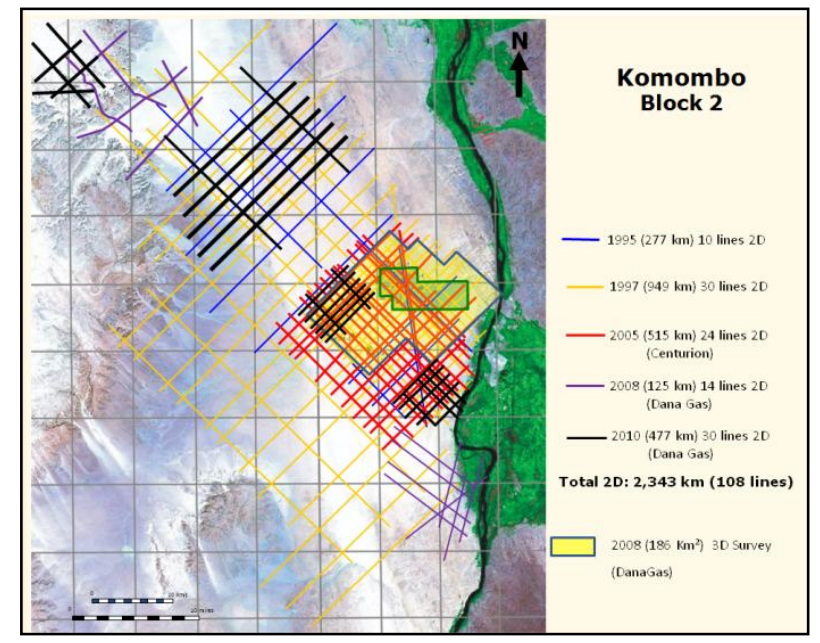

Fig. 5 illustrate 2D and 3D Seismic data that coverage the study Area. 
The seismic data sets used to achieve the goals of this study include 2D and 3D seismic data sets and wells data.The Komombo Basin area covered by two sets of seismic data acquisition about $2343 \mathrm{~km}$ of 2D(108 lines) seismic data and covered about $186 \mathrm{~km} 2$ 3D seismic data acquisitions; fig(5). The Western Desert of Egypt consists of a series of small rift basins. Although some are of Permian age, (3). Structural style of the Western Desert consists of a deep series of low-relief horst and grabens separated by master faults of large throw, and broad Late Tertiary folds at shallower depth. The sub-basins in southern Egypt are controlled by N-S faults defining constant subsiding basins. The E-W Guinea-Nubia this research focuses on the interpretation of the structural of The Komombo Basin Area south of the western desert of Egypt from 3D seismic data, all with the interpretation in this research. Picked Horizons is the first step of the seismic data interpretation .The study area have thick subsurface stratigraphic section including most of the formation which recognized for the south western desert of Egypt, some of this formation tops picked and mapped and interpreted in this research. Six formation tops are picked in the study area; these are Basement, Komombo-A, Komombo-C Six Hills F, Six Hills E, and Abu Ballas Formations.

\subsection{Basement Time Structure Contour map}

The time structural contour map on the top of Basement, based on 3D seismic data Fig. (4-5), shows main general fault trends NW- SE. On the other hand, the time of Basement horizon increase on the southeastern part (structurally low), but the time decreases on the western and northwestern parts of the study area, recording the minimum value down to $1250 \mathrm{msec}$. (structurally high). Fig (6) shows the seismic line \#1300 and interpreted horizons.

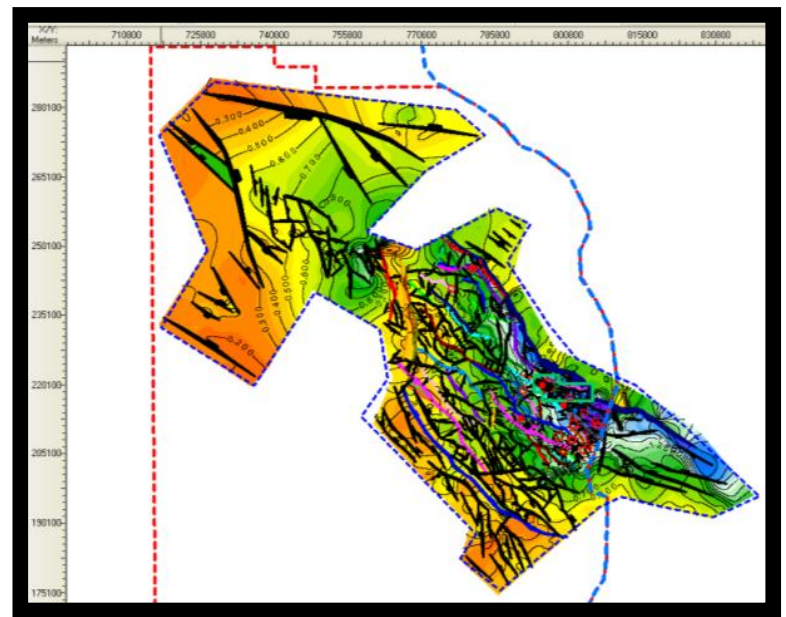

Fig. 6 Time structure contour map on the top of Basement in Komombo basin Area C.I=100 msec.(present Auther).

\subsection{Komombo A Depth Structure Contour map}

The seismic interpretation of top Komombo A member is very important to determine source rock distribution and maturation in this area,based on 3D seismic data Fig 7, The depth structural contour map shows the main fault trends. The major faults in the study area trend in the NW-SE direction with cross element faults in the NS direction and throw towards the eastern direction for some major faults and to the western direction in the other faults,

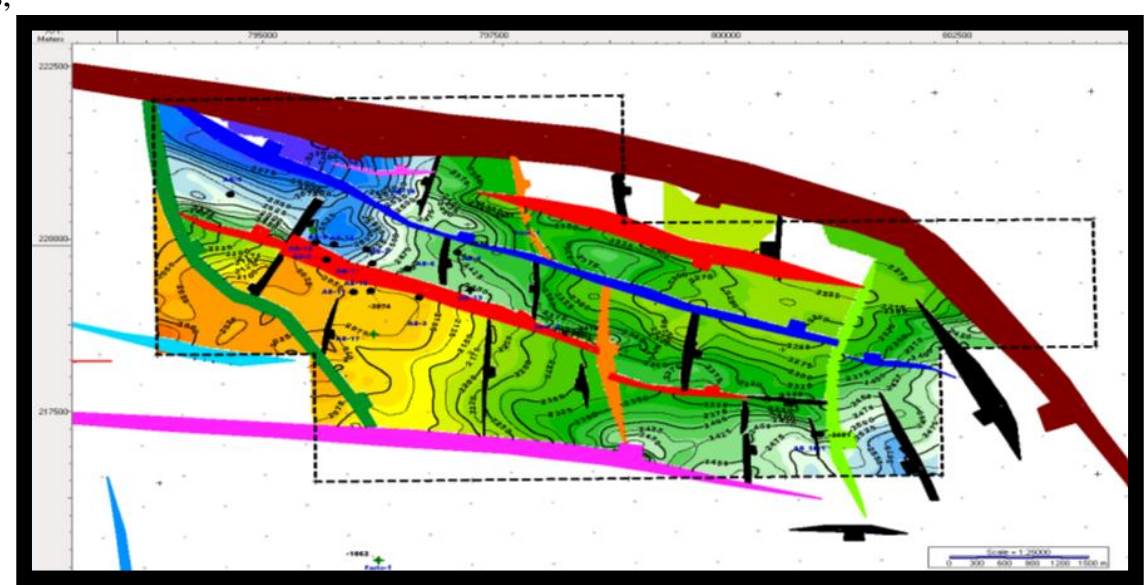

Fig. 7 Depth structure contour map on the top of Komombo A Member in Komombo basin Area C.I=50 m..(after 11). 


\subsection{Komombo C Depth Structure Contour map}

The structural contour map on the top of Komombo C Member, based on 3D seismic data Fig.(8) shows the main fault trends. The major faults in the NS direction and throw towards the eastern direction for some major faults and to the western direction in the other faults. The depth of Komombo C Member increases on the southeastern and eastern parts of the study area,(structurally low). On the other hand, the depth decreases on the western and northwestern parts of the study area. (Structurally high). The study area recording the minimum depth values at $5300 \mathrm{ft}$. in the southwest part of the area and recording the maximum depth values at $8400 \mathrm{ft}$. Komombo C is the reservoir in some wells in Komombo area such as AB-16 which is considered produced well and exists in high area in the step fault from horst .

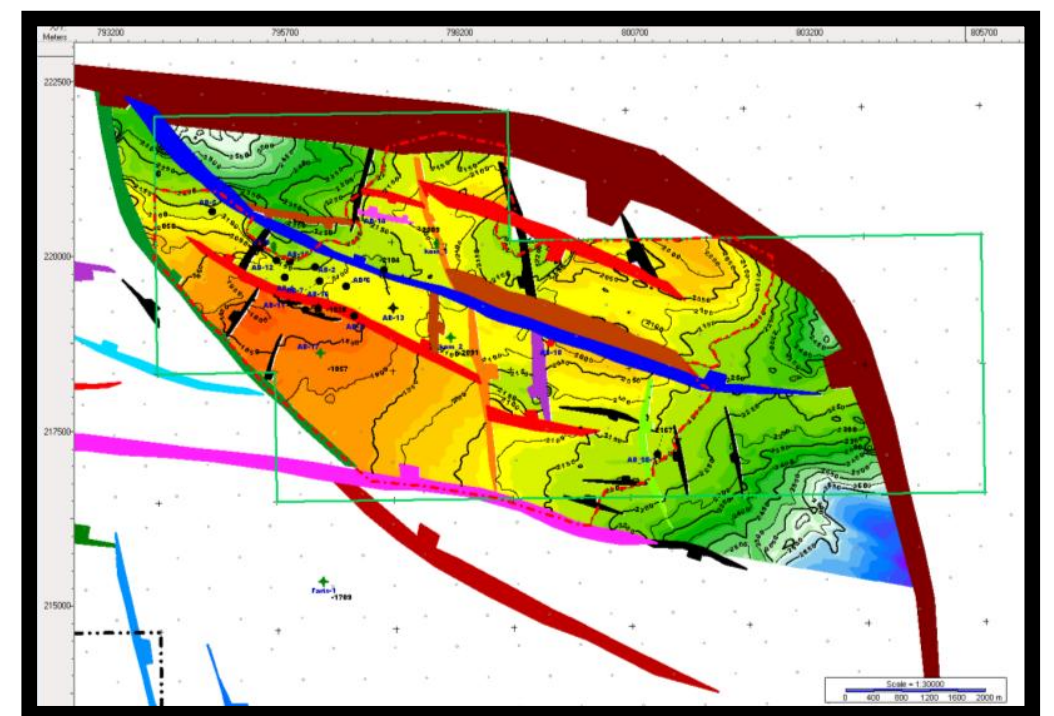

Fig. 8 Depth structure contour map on the top of Komombo C Member in Komombo basin Area C.I=50 m ( after 11).

\subsection{Cretaceous of Six Hills E Depth Structural Contour Map}

Depth structure map of horizon Six Hills E seemed Structural highs are stretch over the field in the northwest direction while structural lows were observed in the southeast, Fig (9). The study area recording the minimum depth values at $3300 \mathrm{ft}$. in the shallowest location of the area and recording the maximum depth values at $5400 \mathrm{ft}$. The basin trend is still in the deepest location of the study area. Six Hills E member is the good reservoir in some wells in $\mathrm{Al}$ Baraka oilfield in AB-4, AB-5, and AB-12. Six Hills E member is an important reservoir in this area the eastern parts of the area recoding the structurally low. but the depth decreases on the near of western and northwestern parts of the study area, recording structurally high in study area trend in the NW - SE direction with cross element faults in the center of the study basin.

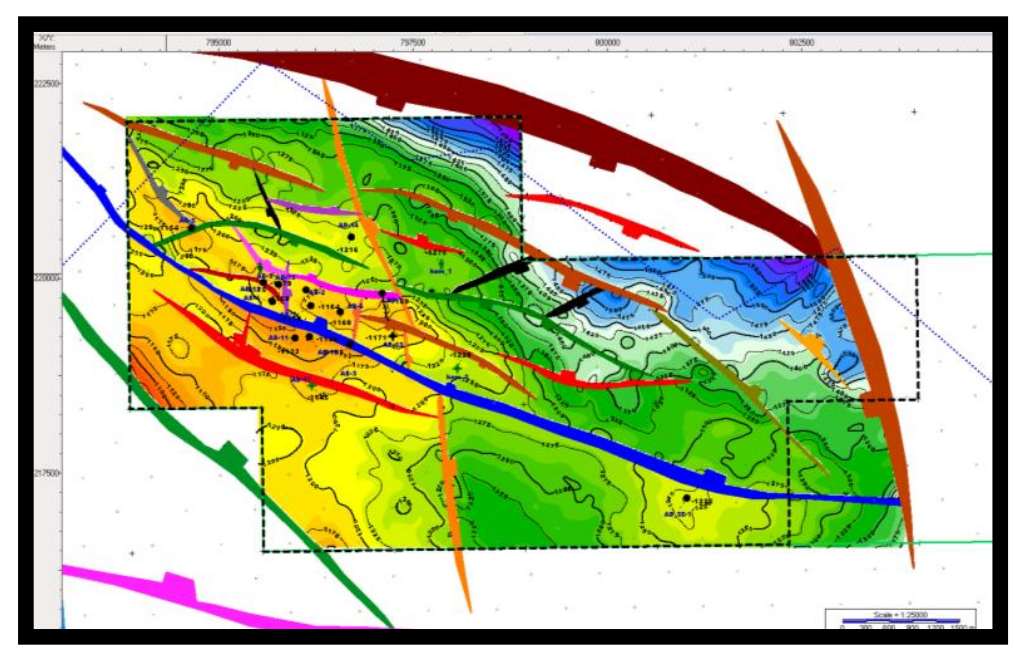

Fig. 9 Depth structure contour map on the top of Six Hills E Member in Komombo basin Area C.I=25 m. (after $11)$. 


\subsection{Cretaceous of Six Hills F Depth Structural Contour Map:}

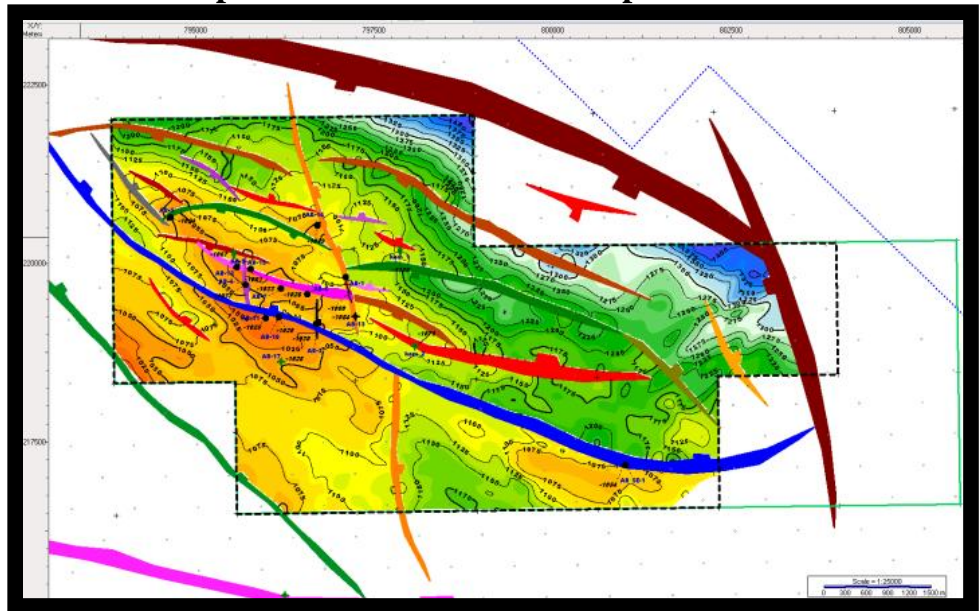

Fig. 10 Depth structure contour map on the top of Six Hills F Member in Komombo basin Area C.I=25 m. (after $11)$.

The seismic data interpretation of Six hills F horizon shows Structural highs are stretch over the field in the northwest direction while structural lows were observed in the southeast. Fig (10). The field fault population is characterized mostly by NW-SE trending faults, Six Hills F member is an important reservoir in this area, as indicated from $\mathrm{Al}$ Baraka wells in AB-6,AB-9 and AB-11.

\subsection{Abu Balas Depth Structural Contour Map}

Horizon and fault interpretation of Abu Ballas Formation shows in the structure highs are stretch over the field in the northwest direction while structural lows were observed in the southeast .Fig (11). The field fault is characterized mostly by NW-SE trending faults that are curvy- shaped. Abu Ballas Formation is an important reservoir in Komombo area. The reservoir rock in the study area, as indicated from Al Baraka wells in AB-1, $\mathrm{AB}-3$ and $\mathrm{AB}-7$

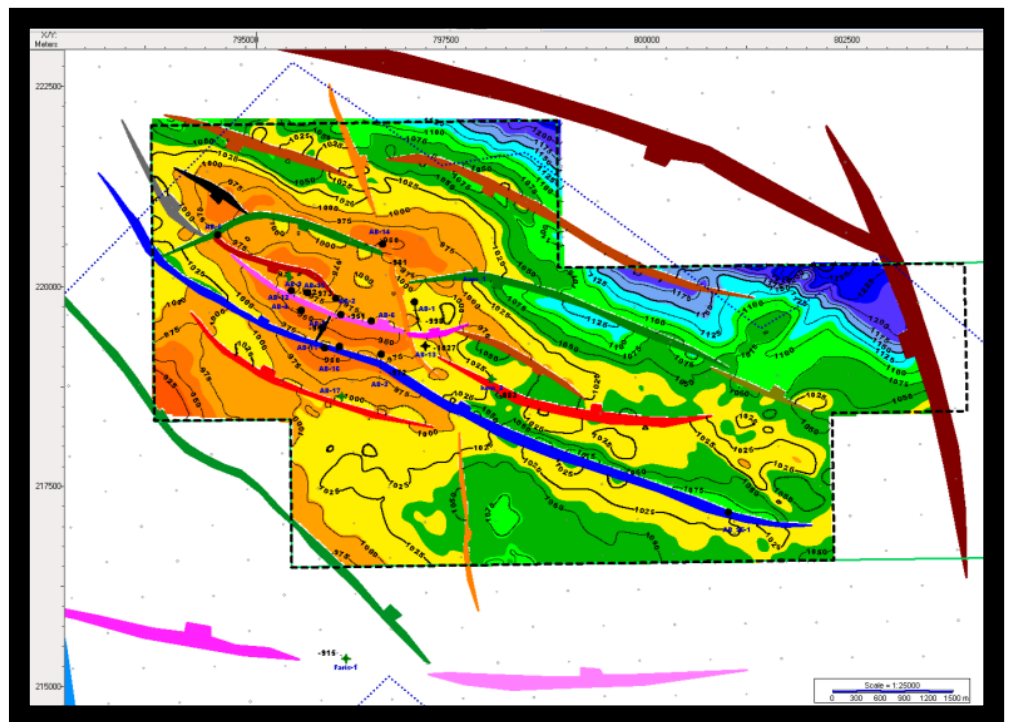

Fig. 11 Depth structure contour map on the top of Abu Ballas Formation in Komombo basin Area C.I=25 m. ( after11).

From Seismic data analysis the major trend are NW-SE ,E-W ,NNW-SSE and NE-SW .

\section{Prospectively in the Study area by using 3D Modeling}

Seismic Horizons, fault interpretation and Depth structure maps of komombo basin input in 3D seismic Model .New seismic data and well data was loaded into PetroMod software to evaluate the stratigraphy and Geochmical composition and to investigate the petroleum system elements of the study area .

3D modeling improved the resolution and extended the model to over $1700 \mathrm{~km} 2$ to improve an assessment by relating the timing of hydrocarbon generation, migration, and accumulation to trap formation, 
through simulation of all the petroleum system elements: charge, reservoir, seal, and traps .Total accumulation were then calculated to show remaining potential zones for prospectively. in the study area discovered only one source rock (Komombo-B) in the deepest part of the komombo basin were already in the oil window during the Early Cretaceous ,presenting 50\% transformation ratio at approximately $80 \mathrm{Ma}$.Source rocks in the Abu Ballas formation represented about $20 \%$ and the Taref coal and Dakhla formation are about $1 \%$.

The Four main reservoirs in the study area showed good potential for hydrocarbon reservoir formation, fed mainly from komombo B source rock, with accumulation represented in structure trap system of anticlines and faults, and stratigraphic trap system of onlap facies boundaries .fig (12)

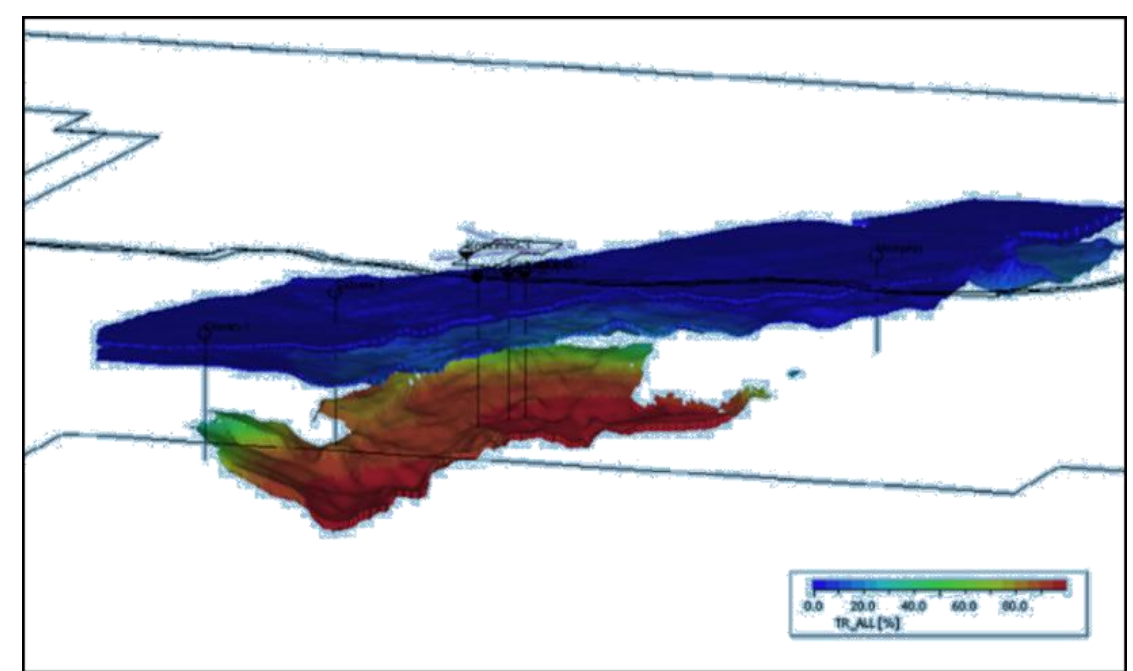

Fig. 123 D simulation model displaying transformation ratio information. (after1).

\section{Conclusion}

Form seismic data interpretation, produce depth structure maps and according to the well results and the basement interpretation in komombo concession we remarked the all wells which drilled in the shallow basement target it was dry and no oil shows. It means this locations has not enough potential and there are not found lateral Migration and may be not have source rock in this prospect, so it's very important for us to interpret Komombo _B formation in this concession to determine the kitchen and The best area of maturation . The Neocomian Shale source rock deposited in Komombo basin area is evaluated as adequate potential source rock which can generate hydrocarbons in Komombo basin. The Neocomian shale is usually present in Komombo basinal area at depths between $8160 \mathrm{ft}-8250 \mathrm{ft}$ in Komombo-2 well and $8190 \mathrm{ft}-8400 \mathrm{ft}$ in $\mathrm{Al}$ Baraka-1 well. The TAI values measured for the kerogen sample; from Neocomian shales of wells; Komombo-2 and Al Baraka-1 range from 2+ to 3 indicating early to mature levels, This means that Neocomian Shale have reached the gas window zone. From this research study, it seem the Amun area and AB-SE, its Promised chargeable area and have good potentiality but to the northern part of this study area at Memphis block there is no charge and long path migration .

\section{Acknowledgements}

The authors would like to express their gratitude thanks to the lab members of the Geology Department, Faculty of science, Al Azher University, for their support during the progress of this study. I wish to thank Komombo Petroleum Company (KOPCO ) for providing the data set and the Egyptian General Petroleum Corporation (EGPC) for permission to publish this work.

\section{References}

[1] Abdelhady, A. (2015): Petroleum system modelling for Komombo basin: Schlumberger case study.

[2] Bosworth, W., El-Hawat, A.S., Helgeson, D.E., Burke, K., 2008. Cyrenaican "shock absorber" and associated inversion strain shadow in the collision zone of northeast Africa. Geology.

[3] Guiraud, (1998): Mesozoic rifting and basin inversion along the northern African Tethyan margin: an overview. In D.S. Mac Gregor, R.T.J. Moody and D.D. Clark-Lowes(Eds.), Petroleum Geology of North Africa. Geological Society of London Special Publication, v. 132, p. 217-229.

[4] Issawi, B., Francis M., Youssef A., Osman R. (2009): The Phanerozoic of Egypt: A Geodynamic Approach, Geological Survey of Egypt, Cairo 2009.

[5] Meshref, W.M (1990): Tectonic Framework: in Said, R. (ed.) :The Geology of Egypt, A.A. Balkema, Rotterdam

[6] Othman et al (2015) : Stratigraphic Column and Petroleum elements of Komombo Basin Area. 
[7] Othman, A. A. A., Ewida, H. F. P., Fathi, M. M. Ali, and Embaby, M. M. A. , (2015): Seismic Inversion for Reservoir Characterization in Komombo Basin, Upper Egypt, (Case Study). International Journal of Innovative Science, Engineering \& Technology, Vol. 2 Issue 9, September 2015.

[8] Said, R., (1962): Tectonic framework of Egypt. In Said, R. (eds.). The geology of Egypt. Elsivier publishing company

[9] Schandelmeier and Reynolds (1997): The Evolution of the Tethys Region throughout the Phanerozoic in South America, Arabia, and South. Africa.

[10] Youssef, M.I., (1968): Structural pattern of Egypt and its interpretation, AAPG Bulletin.

[11] Zakariya ,A.,Abdelhady,A.and Aswany ,M.(2011): Integrated exploration and development approach, Al Baraka Field ,Komombo concession ,upper Egypt ,Egypt .Geophysical Society 26th annual meeting.

Adel A. A. Othman. "Identify a Good New Potential Zones for Hydrocarbon Reservoir Formation, Using
Seismic Data Interpretation, Attributes and 3d Modeling in Komombo Basin, Southern Western Desert, 